\title{
Cultural COMPARISONS FOR HEALING AND EXORCISM NARRATIVES IN Matthew's Gospel
}

Author:

Craig S. Keener ${ }^{1,2}$

\author{
Affiliations: \\ ${ }^{1}$ Department New \\ Testament, Palmer \\ Theological Seminary of \\ Eastern University, United \\ States of America
}

${ }^{2}$ Faculty of Theology,

University of Pretoria,

South Africa

\section{Correspondence to: \\ Craig Keener}

email:

ckeener@eastern.edu

\section{Postal address:}

Palmer Seminary, 6

E. Lancaster Avenue,

Wynnewood, PA 19096,

USA

\section{Keywords:}

Africa; Africans; crosscultural; exorcism; Gospels; healing

\section{Dates:}

Received: 12 Dec. 2009

Accepted: 04 Mar. 2010

Published: 28 July 2010

How to cite this article:

Keener, C.S, 2010,

'Cultural comparisons

for healing and exorcism

narratives in Matthew's

Gospel', HTS Teologiese

Studies/Theological Studies

66(1), Art. \#808, 7 pages.

DOI: $10.4102 /$ hts.v66i1.808

This article is available

at:

http:/ /www.hts.org.za

\section{Note:}

Prof. Dr Craig S. Keener participates as a research associate in the research project 'Biblical Theology and Hermeneutics',

directed by Prof. Dr Andries G. van Aarde, Honorary Professor of the Faculty of Theology at the University of Pretoria, South Africa.

(C) 2010. The Authors. Licensee: OpenJournals Publishing. This work is licensed under the Creative Commons Attribution License.

\section{ABSTRACT}

Majority World readings of Matthew (and the Gospels generally) often help us to appreciate the very sorts of stories that seem most alien to readers in the West: stories of unusual cures and exorcisms of hostile spirits. Rather than simply allegorising these narratives, many Majority World readers treat them as models for experiencing healing and deliverance. Accounts of these experiences appear in a wide variety of cultures; in addition to a range of published sources, the article includes some material based on the author's interviews with people claiming first-hand experiences of this nature in the Republic of Congo. Such readings invite a more sympathetic hearing of some Gospel narratives than they often receive in the West.

\section{INTRODUCTION}

Western readers of the healing and exorcism narratives in the Gospels may learn from readings from different social locations, particularly those from cultures where such experiences are more widely considered than in the West. (Although I specify Matthew as an example, the approach has relevance to any of our extant 1st-century Christian narrative works, i.e. the Gospels and Acts.) The extent to which scholars are interested in readings from various social locations naturally differs according to the primary focus of the scholars. Yet even when a scholar's interest is largely in reconstructing the most obvious readings of Matthew in its 1st-century context (as mine usually is: e.g. Keener 2005, 2009b, 2009d), readings from diverse social locations help identify blind spots and lacunae in our reasoning. Like reception history, readings from various social locations can raise issues that our own cultural assumptions tend to neglect. ${ }^{1}$

Although Matthew clearly applies Jesus's healings in symbolic theological ways (see, e.g., the Christological emphasis in Held 1963) and I, as well as others, recognise this symbolism (e.g. Keener 2009b:273, 290, 298, 380-381), he does not downplay miracles as some scholars have argued (see the correct critique in Heil 1979:276). To strip expectations of special divine action from the miracle stories is likely to neglect one central element of the theology of the narratives that the first audiences would have heard, preferring allegorisation to understanding what the narratives meant in their earliest contexts. ${ }^{2}$ We do not play down the physical dimensions of healing claims with regard to shrines of Asclepius, for example; rather, we recognise their propagandistic invitation to trust Asclepius for more healings. Is it not possible that the Gospel writers (perhaps some more than others) offered the same sort of invitation, given the emphasis on prayers in faith (e.g. Mt 7:7-11, 17:20, 21:21) and texts suggesting that Jesus modelled miracle working for at least some members in his movement (Mt 9:35-10:1, 14:28-31)? We may illustrate this recognition by the characteristic interpretations of these narratives in sayings least shaped by Western perspectives.

Some scholars (including myself) have also examined some early Christian healing narratives in the light of ancient views on sickness and medicine, though most commonly with respect to Luke-Acts (Keener 2009a; Weissenrieder 2003). ${ }^{3}$ Although the audiences of the Gospels were undoubtedly not literate in ancient medical sources, reading these ancient sources can bring us closer to how 1st-century audiences understood many of these ailments and their symptoms, as opposed to the ways that we intuitively read these texts. More generally, however, the currently burgeoning field of medical anthropology can expand our cultural horizons in reading healing texts in the Gospels and Acts, as John Pilch and others have emphasised (Pilch 2000:35). ${ }^{4}$ Some other disciplines have been quicker to appropriate the benefits of medical anthropology. Indeed, some physicians now partner with some 'spiritual healers' due to the observed effectiveness of some of the latter, regardless of views of the causes (Remus 1997:114-115). My use of examples here and below is not meant to pass judgment on the causes of such experiences but simply to note that they are part of human experience in most cultures, as they appear to have been part of human experience in 1st-century Palestine. Readings that allow for this experience will be more sympathetic than those revolted by it.

\section{THE CROSS-CULTURAL READINGS OF OTHERS}

Culture affects how we read ancient miracle claims. Whereas Western critics have sometimes explained away or neglected accounts of paranormal healing, ${ }^{5}$ most Christians in the Majority World, less shaped

1.Much of my discussion that follows here involves research for my forthcoming book on this global reading of miracle narratives; see Keener 'Miracles: The plausibility of healing accounts in the Gospels and Acts' (in press), especially chapters 7-9, 12.

2.Although allegorical readings are ancient, the theologically or apologetically motivated temptation to play down 'supernatural' readings is largely post-Humean. The practice of deriving only spiritual applications from accounts of Jesus's healings has a long history, including in 18th-century cessationist Protestantism (see Kidd 2006:166).

3.For one study of Paul using information from medical sources, see Martin 1995

4.For medical anthropology in general, see Pilch 2000:19-36; for application-to-Jesus research, see Pilch 1995; for various applications of anthropology more generally to NT healing accounts, see Neyrey 1999. On various cultural systems approaching disease differently, see, for example, Grundmann 2001:33.

5.Our Western approach has often been shaped by Hume, who argued among other points that miracle reports are largely the domain 
by the modern Western tradition of the radical Enlightenment, find stories of miraculous phenomena far less objectionable. These other cultures offer a check on traditional Western assumptions; as Lamin Sanneh, Professor of Missions and History at Yale Divinity School, points out, it is here that Western culture 'can encounter ... the gospel as it is being embraced by societies that had not been shaped by the Enlightenment, hence are closer to the milieu of earliest Christianity (Sanneh 2003:26). Even various Western scholars are increasingly challenging the hegemony of the traditional Western approach of demythologising, in light of the very different hermeneutical approach of most African readers (see e.g. Kahl 1998).

When historian Ramsay MacMullen compares the healings of Simon Kimbangu (1889-1951) from 1921 in the Belgian Congo with Christian claims in the Roman Empire, he warns against extrapolating from anthropological parallels. Nevertheless, he believes that Kimbangu's 'story might alert us to points in the evidence from antiquity which deserve special attention (MacMullen 1984:7). ${ }^{7}$ Kimbangu's followers affirmed that he 'raised the dead, caused the paralyzed to stand upright, gave sight to the blind, cleansed lepers, and healed all the sick in the name of the Lord Jesus' (Koschorke, Ludwig \& Delgado 2007:260, quoting an early document of the Kimbanguist Church). (Not unlike Jesus, he also ran afoul of the colonial elite who were anxious about the political potential of prophetic movements. $)^{8}$

Rapidly expanding movements like Kimbangu's (although the movement's current form differs from its original impetus $)^{10}$ and William Wadé Harris's healing ministry in West Africa (1913$1915)^{11}$ can be helpful in expanding the conceptual parameters of Western readers unaccustomed to thinking in terms of such phenomena. Others have compared the documented curing successes of the "'mad monk" Rasputin,' which affected the course of Russian history and therefore cannot be omitted from historical inquiry (McClymond 2004:83, though Rasputin is hardly an unambiguously positive figure). Still others have compared Don Pedrito Jaramillo, a Mexican folk saint active from 1881 until 1907, who achieved more notoriety than other healers of his era (Eve 2002:357-359). Other scholars have noted how quickly Western commentators have tended to pass over early Christian signs claims, often in embarrassment (Ashton 2000:174-75, 177, noting that MacMullen differs from most NT scholars here). (Anthropologists reading the New Testament are not always so reticent: e.g. Field 1969:10; cf. Kim 2006:32.) One critic of this embarrassed silence in Western New Testament scholarship has compared biblical examples with literature about shamans from around the world (Ashton 2000:32-40). ${ }^{12}$

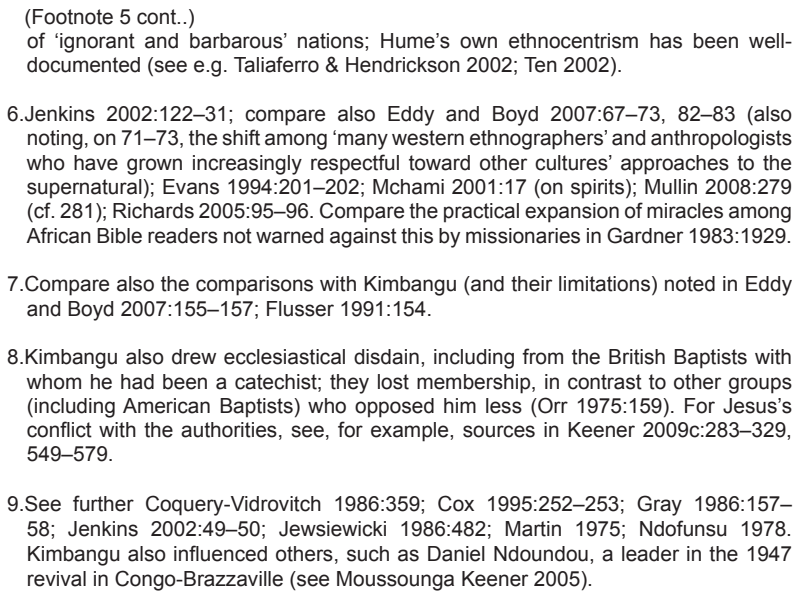

6.Jenkins 2002:122-31; compare also Eddy and Boyd 2007:67-73, 82-83 (also noting, on 71-73, the shift among 'many western ethnographers' and anthropologists who have grown increasingly respectful toward other cultures' approaches to the supernatural); Evans 1994:201-202; Mchami 2001:17 (on spirits); Mullin 2008:279 (cf. 281); Richards 2005:95-96. Compare the practical expansion of miracles among African Bible readers not warned against this by missionaries in Gardner 1983:1929.

7.Compare also the comparisons with Kimbangu (and their limitations) noted in Eddy and Boyd 2007:155-157; Flusser 1991:154.

8.Kimbangu also drew ecclesiastical disdain, including from the British Baptists with whom he had been a catechist; they lost membership, in contrast to other groups (including American Baptists) who opposed him less (Orr 1975:159). For Jesus's (including Ameican Baptists) who opposed him less (On 1975:159). For Jesus's

9.See further Coquery-Vidrovitch 1986:359; Cox 1995:252-253; Gray 1986:15758; Jenkins 2002:49-50; Jewsiewicki 1986:482; Martin 1975; Ndofunsu 1978. Kimbangu also influenced others, such as Daniel Ndoundou, a leader in the 1947 revival in Congo-Brazzaville (see Moussounga Keener 2005).

10.For some of Kimbangu's followers deifying him, see Kalu 2008:70, 78-79.

11. Also cited by MacMullen 1984:23-24. Harris is widely remembered and discussed; see Bediako 1995:91-93, 103-104, 204; Haliburton 1973; Kalu 2008:20, 31, 3638; Mullin 2008:275; Shank 1994; Walker 1983; Walls 1996:87-88, 98-99.

12.For shaman analogies, compare also, for example, Craffert 2003; Klutz 2004:196-
One need not look far for such claims; one could take for example the global Pentecostal and charismatic movement, which has achieved phenomenal growth in one century. Although some more conservative estimates may be closer to the mark, most observers today estimate at least half a billion Pentecostals and charismatic Christians in the world today (e.g. Cox 1995:xv, 1997:88; Mullin 2008:272; Sanneh 2008:275) Emphasising Pentecostalism's growth in the Global South, where it is especially flourishing and culturally relevant, ${ }^{13}$ historian Robert Bruce Mullin observes that already by the end of the 20th century there were 'more Pentecostals worldwide' than mainline Protestants (Mullin 2008:211; cf. 276).

The Pew Forum conducted a 10-country survey of Pentecostals and charismatics and, in October 2006, issued a 231-page report (Pew Forum Survey 2006). In these 10 countries alone, and for Pentecostals and charismatics in these countries alone, the estimated number of people claiming to have "witnessed divine healings' comes to 202141082 (i.e. about 200 million). What may be more interesting in this survey, however, is the category of 'other Christians', with somewhere around 39 per cent in these countries claiming to have 'witnessed divine healings'. That is, over one-third of Christians worldwide who do not identify themselves as Pentecostal or charismatic claim to have witnessed divine healings.

Nor are paranormal claims by any means restricted to Christian movements. Most non-Western worldviews accept a variety of suprahuman phenomena (e.g. Turner et al. 1992, passim; Wright 1955:74-114, esp. 85-88, 95-98). John Pilch suggests that 90 per cent of the world today accepts both 'ordinary reality and nonordinary reality', the latter including God and spirits (Pilch 2004:17). It is not even possible to survey here the voluminous and rapidly expanding anthropological literature on healing claims from various traditional cultures. ${ }^{14}$

Gerd Theissen and Annette Merz rightly warn that, against most 20th-century academic expectations, many cultures today offer a range of miracle claims (Theissen \& Merz 1998:310; cf. also Price 2003:20-21). Some Latin American scholars complain that those scholars who deny that modern people believe in miracles work with an extremely culturally constricted understanding of the 'modern world' (González 2001:84-85) $\cdot^{15}$ Other scholars note that as the centre of world Christianity has shifted to the Global South, the dominant Christian perspectives in the world have shifted with it (Laing 2006:165). Readings of Scripture in the Global South often contrast starkly with modern Western critics' readings. ${ }^{16}$ These readings from other social locations often shock Westerners not only because others believe the early Christian miracle narratives to be plausible; they astonish many Westerners because these readers also often take these narratives as a model for ministry (see e.g. Green 2002:9-10; Noll 2009:24, 33-34, 35-36, 123). Thus, a Western scholar of global Christianity, Philip Jenkins, notes that in general Christianity in the Global South is quite interested in 'the immediate workings of the supernatural, through prophecy, visions, ecstatic utterances, and healing' (Jenkins 2002:107).

(Footnote 12 cont...)

197: Pilch 2008:100 (Jesus as a folk healer); discussion in Porterfield 2006:163; Van Aarde 2008. For the perspective that shamanistic healing is a cross-cultural phenomenon (at its most basic level), see Winkelman and Carr 2006:171.

13.For Pentecostalism in the Majority World, see, for example, Anderson 2004:72-73, 111-113, 116, 130; Jenkins 2002:122-131; A. Yong 2005:33-80. For its growth in much of Asia, see, for example, Ma 1999:195-196; Ma 2005; Yung 2005; in Latin America, see Petersen 1996, 2006; in Africa, Maxwell 2006:6-7.

14.I note here only a tiny sample: Desjardlais 1992; Greenfield 2008; Krippner and Achterberg 2000; Scherberger 2005:59-64; Straight 2007; Stoller and Olkes 1987; Turner 2006

15.See similarly Martell-Otero 2004:384-387. The Latin American worldview is more accepting of the supernatural, not being 'over-rationalized' (Alvarez 2002:141-142, 144 , though referring esp. to Pentecostals).

16.See Van der Watt 2008, especially 237-242 (though warning of the danger of ignoring original contexts, 243). 
Such an approach, closer to the early Christian worldview than modern Western culture, appeals to many traditional non-Western cultures. ${ }^{17}$ Hwa Yung, bishop of the Methodist church in Malaysia, notes that the charismatic character of most Majority World churches reflects not so much direct influence by Pentecostals or charismatics as simply the worldview of the majority of humanity. They have simply never embraced the Western, mechanistic, naturalistic Enlightenment worldview that rejects the supernatural (Yung 2007:173). Nigerian psychologist Regina Eya (1992:51-52) warns that all claims to paranormal healing are dismissed by many Western scholars, the credible along with the spurious, because of the inappropriate application of traditional Western scientific paradigms to matters for which they were not designed. ${ }^{18}$

\section{EXAMPLES FROM INTERVIEWS IN THE REPUBLIC OF CONGO}

I offer hundreds of examples of global healing claims from various sources in my forthcoming study on the subject, but here I simply introduce the subject by noting some healing claims from within the family of my wife, a historian from the Republic of Congo, or among close friends of her family.

My father-in-law, Jacques Moussounga, a retired railroad worker and mainline Protestant deacon in Congo, shared with me that he had painful mouth abscesses for over 20 years. After he had joined a small prayer group in Brazzaville, the leader, Suzanne Makounou, dreamt that he was experiencing terrible pain from mouth abscesses and consequently reproved him for not having requested prayer. About a month and a half after she had prayed for him, he noticed that the abscesses were gone and they never returned (pers. comm., 8 September 2005). He, in the same correspondence, and his wife, Antoinette Malombe (in an interview on 12 July 2008), also shared with me how their baby daughter had been dying of meningitis; Barthélémy Boubanga, a hospital administrator, warned that the baby would not live through that night. Papa Jacques prayed by the bed all night and, in the morning, the French doctor and nurse who entered were surprised that the baby was recovering, attributing the recovery to God. The child, Gracia, is now in her thirties. My wife and others (such as H. Mabiala, in an interview in Brazzaville, Republic of the Congo, on 24 July 2008) have told me how they recovered instantly from fevers or other conditions when Papa Jacques prayed for them.

While such recoveries, which are known to happen at times, will not surprise most Western readers, other reports are more likely to shock us. For example, the family's eldest daughter, Thérèse Magnouha, at the age of two, cried out that a snake had bitten her; her father was away on business in another town. My motherin-law, Antoinette Malombé, reported in our interview that the child had stopped breathing and no medical care was available anywhere nearby. Antoinette Malombé had therefore strapped the child to her back and had run as best as she could to a nearby village to ask Coco ('Grandfather') Ngoma Moïse, an evangelist friend of the family, to pray. When he prayed, the child began to breathe and she had recovered fully by the next day. When I asked how long Thérèse had not been breathing, Mme. Jacques (as my mother-in-law is locally known) calculated how long it would have taken her to reach Coco Moïse and unpretentiously explained that it would have been about three hours. ${ }^{19}$ Thérèse recently finished her master's degree at a seminary in Cameroon.

In an interview on 29 July 2008, a close friend of the family, Jeanne Mabiala, a deacon in the same denomination, shared with

17.See, for example Pocock, Van Rheenen and McConnell 2005:136-137. For the relevance of Pentecostal-like experience to indigenous healing traditions as well as offering a connection to the Gospels and Acts, see also Porterfield 2005:126; J. Yong 2005:401.

18.Compare Manus 1989; Mbiti 1970:253; Mensah 2008:177-179; Roschke 2006.

19.We confirmed the story telephonically with Ngoma Moïse on 14 May 2009. The story has long circulated in the family. me a number of firsthand stories, including three resuscitations of persons believed dead; in some cases I was able to talk with witnesses who corroborated these experiences..$^{20}$ One of these cases involves a woman named Marie, from Passi-Passi, a village outside Dolisie. Marie was suffering from malaria and was severely anaemic, Mama Jeanne was told that she had not eaten, drunk or opened her eyes for three weeks. The family lacked money for the hospital, yet brought her into Dolisie anyway. At this time, however, according all witnesses present, she died. Having heard about the prayer meetings at Mama Jeanne's home, they brought her there and laid her on a mat. As Mama Jeanne began to pray, Marie began to stir slowly and within a short period of time was even able to walk; they got care for her illness in the hospital, where she recovered fully.

In the book I am writing, I am collecting many more claims (both from written sources and interviews) from various parts of the world. We might attribute many claims to the placebo effect or other factors ${ }^{21}$; such explanations appear more complicated for some other reports. Yet whatever one makes of these claims (which is not the point here), they reflect a worldview quite different from and more amenable to appreciating the holistic, physical value of biblical miracle claims than that of most Western scholars. Reading Matthew's miracle claims from a Majority World context offers an opportunity to hear these texts with greater sympathy, closer to the way the first audiences of the Gospels and Acts would have heard them.

\section{CROSS-CULTURAL READINGS OF POSSESSION ACCOUNTS ${ }^{22}$}

An increasing number of scholars have used cross-cultural studies of possession and exorcism to place early Christian accounts in a broader context. ${ }^{23}$ (For the sake of brevity, I abridge this discussion even more thoroughly than my previous one.) One danger of this approach is that scholars could ignore significant differences among how various cultures conceptualise or classify the experiences grouped together under these labels. A significant benefit, however, is that they take us beyond our modern Western assumptions that prevent us from sympathetically hearing the ancient texts we are studying.

Despite various interpretations assigned to it, no anthropologist today denies possession trances and the like. ${ }^{24}$ Possession experience is not limited to either the New Testament or the ancient eastern Mediterranean world, though it appears in both places. One specialist, Erika Bourguignon, has observed that spirit-possession beliefs are geographically and culturally pervasive, '[a]s any reader of ethnographies knows' (Bourguignon 1976:18). ${ }^{25}$ After sampling 488 societies, she found spirit possession beliefs in 74 per cent of them (i.e. 360 societies), with particularly high ranges in the islands of the Pacific ( 88 per cent) and 77 per cent around the Mediterranean (Bourguignon 1973a, 1976:19-21). Among these, the forms of 'possession' vary.

20.Other witnesses to some of these experiences were Emmanuel Nzaou (interviewed on 29 July 2008) and my brother-in-law, Emmanuel Moussounga, a university science professor (interviewed on 29 July 2008). Other raising accounts were reported by another family friend in the Republic of Congo, Albert Bissouessoue (interviewed on 17 December 2009)

21.See, for example, Droege 1991:15-33 (esp. 23-26; cf. also pp. 9-12, on psychoneuroimmunology); Remus 1997:110-13; Greenfield 2008:18, 180, 201.

22.I treat this material in substantially more detail in Keener, 'Spirit possession as a cross-cultural experience' (in press)

23.Borg 1987:62; Crossan 1991:315-317; Eddy and Boyd 2007:67-69; for LukeActs, see Klutz 2004:196-197; at greater length, see Keener, 'Spirit possession as a cross-cultural experience' (in press)

24. Such a denial has been regarded as the anthropological equivalent of 'being a "flatearther"' (Burridge 1969:4 n. 2, as cited in Lewis 1989:321-322 n. 15).

25.Compare also Boddy 1994:409; Bourguignon 1965, 1973c:17-19; Firth 1969:ix; Lewis 1971:100-126; Morsy 1991:189. For the wide geographic distribution of cultures practising trance, possession trance and spirit possession, with maps, see Bourguignon 1968:18-32. 
Thus 16 per cent of these 360 societies have possession trance only, 22 per cent have other forms of possession and 35 per cent have both (Bourguignon 1976:21). The overall evidence suggests some sort of common experience in conjunction with more specific cultural patterning.

Transcultural elements, in fact, include a biological element that cannot be reduced to (though may be patterned according to) cultural models. Studies reveal 'an altered neurophysiology' during many possession states (Prince 1968:127-129). In a diverse sampling of societies, possession produces major personality changes, with notable, abrupt alterations in voice and other features (see e.g. Gelfand 1962:169; Mbiti 1970:225-226; Oesterreich 1966:19-22; Shorter 1985:177; Tippett 1976:162-164). Those leaving the 'possession' state often have no recollection of how they acted while 'possessed' (e.g. Field 1969:3, 6; Gelfand 1962:166, 169; Horton 1969:23; Rosny 1985:185-186; cf. Singleton 1978:477). Thus Raymond Firth (1969), mentioning his own astonishment, notes that field experience has confronted social anthropologists with

dramatic changes of personality in men or women they were studying-startling yet evidently accustomed alterations of behaviour, with trembling, sweating, groaning, speaking with strange voices, assumption of a different identity, purporting to be a spirit not a human being, giving commands or foretelling the future in a new authoritative way. Sometimes it has been hard for the anthropologist to persuade himself that it is really the same person as before whom he is watching or confronting, so marked is the personality change.

(Firth 1969:x)

Sometimes the possessed act like the spirits that are believed to possess them (see e.g. Verger 1969:50-51, 53).

Nevertheless, possession behaviour often conforms to patterns particular to the cultures where it appears (see e.g. Firth 1967:313-314; Southall 1969:243; Verger 1969:64; for e.g. some proposed common traditional African characteristics, see JulesRosette 1980:273-285) and some possessed persons respond in stereotypical manners (e.g. Gussler 1973:123-124; cf. Kaplan \& Johnson 1964:206). Thus, for example, Somali possession cults do not emphasise different spirits with distinct behaviours (in contrast to related Sudanese cults); although the possessed dance, they speak little (in contrast to, say, Comoro island possession [Luling 1991:175]). In traditional Ghana, possession often begins with a stupor and then becomes frenzied (Field 1969:3-4); a spirit may possess an established diviner to provide information as to what deity is possessing another person (Field 1969:8). Among traditional Valley Korekore, mediums through whom spirits speak are fairly rare and typically must remain in the area belonging to the spirit possessing them; by contrast, possession more generally is common there and cult groups dance it out (Garbett 1969:105). Reviewing such diversity of experience, Bourguignon (1973b:337) remarks that despite transcultural constants stemming from its psychobiological substrate,' possession behaviour 'is subject to learning and by this means, it is amenable to cultural patterning. As such, it takes on a striking variety of forms'.

Beyond psychosocial theories, diverse cultures offer a vast range of interpretations for possession trance (see e.g. Lewis 1971:44; cf. also Peters 1981:11-16, 46-47, 50). Societies diverge, for example, as to whether they prefer naturalistic or supernaturalistic explanations (Bourguignon 1968:4-11). Not unexpectedly, naturalistic expectations predominate in the West, ${ }^{26}$ though they sometimes appear elsewhere (Bourguignon 1968:6). The dominant supernaturalistic or mystical explanations include soul absence or the presence of a spirit (Bourguignon 1968:7-12; Lewis 1971:64). Cultures vary as to whether they treat trance behaviour as positive or negative (Bourguignon

26.For example, many offer psychological explanations, such as the emergence of repressed subconscious thoughts (e.g. Singleton 1978:475); certainly this appears to be the case in some instances (see e.g. Lewis 1969:201-203)
1968:6-7, 13-15) $)^{27}$; these and other interpretations influence how people in trance states behave (Bourguignon 1968:12). While interpretations vary, readers in a range of societies would approach the accounts in the Gospels with less embarrassment and more sympathy than is usual in many modern Western readings.

One could explore all these questions in substantially more detail, but I introduce them as one area where Gospels scholars have so far done only limited research, yet where I believe that further research could expand our culturally conditioned range of interpretive options.

\section{CONCLUSION}

I believe that many Majority World readings of Matthew can help us to appreciate the very sorts of stories that seem most alien to us in the West: stories of unusual cures and exorcisms of hostile spirits. While we are not obliged to embrace all alternative explanations of these experiences, we are obliged to consider the stories these other readers offer and welcome their voices into the dialogue.

\section{REFERENCES}

Alvarez, M., 2002, 'The South and the Latin America paradigm of the Pentecostal movement', Asian Journal of Pentecostal Studies 5(1), 135-153.

Anderson, A., 2004, An introduction to Pentecostalism: Global charismatic Christianity, Cambridge University Press, Cambridge.

Ashton, J., 2000, The religion of Paul the Apostle, Yale University Press, New Haven.

Bediako, K., 1995, Christianity in Africa: The renewal of a nonWestern religion, Edinburgh University Press, Edinburgh.

Boddy, J., 1994, 'Spirit possession revisited: Beyond instrumentality', Annual Review of Anthropology 23, 407-434.

Borg, M.J., 1987, Jesus: A new vision (spirit, culture, and the life of discipleship), Harper \& Row, San Francisco.

Bourguignon, E., 1965, 'The self, the behavioral environment, and the theory of spirit possession', in M.E. Spiro (ed.), Culture and meaning in cultural anthropology, n.p., Free Press, New York.

Bourguignon, E., 1968, 'World distribution and patterns of possession states', in R. Prince (ed.), Trance and possession states, pp. 3-34, R.M. Bucke Memorial Society, Montreal.

Bourguignon, E., 1973a, 'Appendix', in E. Bourguignon (ed.), Religion, altered states of consciousness, and social change, pp. 359-376, Ohio State University, Columbus.

Bourguignon, E., 1973b, 'An assessment of some comparisons and implications', in E. Bourguignon (ed.), Religion, altered states of consciousness, and social change, pp. 321-339, Ohio State University, Columbus.

Bourguignon, E., 1973c, 'Introduction: A framework for the comparative study of altered states of consciousness', in E. Bourguignon (ed.), Religion, altered states of consciousness, and social change, pp. 3-35, Ohio State University, Columbus.

Bourguignon, E., 1976, 'Spirit possession belief and social structure', in A. Bharati (ed.), The realm of the extra-human: Ideas and actions, pp. 17-26, Mouton Publishers, The Hague.

Burridge, K., 1969, New heaven, new earth, Basil Blackwell, Oxford.

Coquery-Vidrovitch, C., 1986, 'French black Africa', in A.D. Roberts (ed.), The Cambridge history of Africa, vol. 7: From 1905-1940, pp. 329-392, Cambridge University Press, Cambridge.

Cox, H., 1995, Fire from heaven: The rise of Pentecostal spirituality and the reshaping of religion in the twenty-first century, Addison-Wesley, Reading.

27.Some societies have trance without possession, others possession without trance and still others possession trance (Bourguignon 1968:18, 1976:21-22). 
Cox, H., 1997, 'Into the age of miracles: Culture, religion, and the market revolution', World Policy Journal 14(1), 87-95.

Craffert, P.F., 2003, 'Crossan's historical Jesus as healer, exorcist and miracle worker', Religion \& Theology 10 (3\&4), 243-266.

Crossan, J.D., 1991, The historical Jesus: The life of a Mediterranean Jewish peasant, HarperSanFrancisco, San Francisco.

De Rosny, E., 1985, Healers in the night, Orbis, Maryknoll.

Desjardlais, R., 1992, Body and emotion: The aesthetics of illness and healing in the Nepal Himalayas, University of Pennsylvania, Philadelphia.

Droege, T.A., 1991, The faith factor in healing, Trinity Press International, Philadelphia.

Eddy, P.R. \& Boyd, G.A., 2007, The Jesus legend: A case for the historical reliability of the synoptic Jesus tradition, Baker Academic, Grand Rapids.

Evans, C.S., 1994, 'Critical historical judgment and biblical faith', Faith and Philosophy 11(2), 184-206.

Eve, E., 2002, The Jewish context of Jesus' miracles, Journal for the Study of the New Testament Supplement Series 231, Sheffield Academic Press, London.

Eya, R., 1992, 'Healing and exorcism: The psychological aspects', in C.U. Manus, L.N. Mbefo \& E.E. Uzukwu (eds.), Healing and exorcism: The Nigerian experience, pp. 44-54, Spiritan International School of Theology, Attakwu-Enugu.

Field, M.J., 1969, 'Spirit possession in Ghana', in J. Beattie \& J. Middleton (eds.), Spirit mediumship and society in Africa, pp. 3-13, Africana Publishing Corporation, New York.

Firth, R., 1967, Tikopia ritual and belief, Beacon, Boston.

Firth, R., 1969, 'Foreword', in J. Beattie \& J. Middleton (eds.), Spirit mediumship and society in Africa, pp. ix-xiv, Africana Publishing Corporation, New York.

Flusser, D., 1991, 'Jesus, his ancestry, and the commandment of love', in J.H. Charlesworth (ed.), Jesus' Jewishness: Exploring the place of Jesus within early Judaism, pp. 153-176, Crossroad Publishing Company, New York.

Garbett, G.K., 1969, 'Spirit mediums as mediators in Valley Korekore society', in J. Beattie \& J. Middleton (eds.), Spirit mediumship and society in Africa, pp. 104-127, Africana Publishing Corporation, New York.

Gardner, R., 1983, 'Miracles of healing in Anglo-Celtic Northumbria as recorded by the Venerable Bede and his contemporaries: A reappraisal in the light of twentiethcentury experience', British Medical Journal 287(Dec. 24-31), 1927-1933.

Gelfand, M., 1962, Shona religion: With special reference to the Makorekore, Juta \& Company, Cape Town.

González, J.L., 2001, Acts: The Gospel of the Spirit, Orbis, Maryknoll.

Gray, R., 1986, 'Christianity', in A.D. Roberts (ed.), The Cambridge history of Africa, vol. 7: From 1905-1940, pp. 140-190, Cambridge University Press, Cambridge.

Green, M., 2002, Thirty years that changed the world: The Book of Acts for today, Eerdmans, Grand Rapids.

Greenfield, S.M., 2008, Spirits with scalpels: The cultural biology of religious healing in Brazil, Left Coast Press, Walnut Creek.

Grundmann, C.H., 2001, 'Healing - A challenge to church and theology', International Review of Mission 90(356 \& 357), 26-40.

Gussler, J.D., 1973, 'Social change, ecology, and spirit possession among the South African Nguni', in E. Bourguignon (ed.), Religion, altered states of consciousness, and social change, pp. 88-126, Ohio State University Press, Columbus.

Haliburton, G.M., 1973, The Prophet Harris, Longmans, London.

Heil, J.P., 1979, 'Significant aspects of the healing miracles in Matthew', Catholic Biblical Quarterly 41, 274-287.

Held, H.J., 1963, 'Matthew as interpreter of the miracle stories', in G. Bornkamm, G. Barth \& H.J. Held (eds.), Tradition and interpretation in Matthew, pp. 165-299, SCM, London.

Horton, R., 1969, 'Types of spirit possession in Kalabari religion', in J. Beattie \& J. Middleton (eds.), Spirit mediumship and society in Africa, pp. 14-49, Africana Publishing Corporation, New York.

Jenkins, P., 2002, The next Christendom: The coming of global Christianity, Oxford University Press, New York.
Jewsiewicki, B., 1986, 'Belgian Africa', in A.D. Roberts (ed.), The Cambridge history of Africa, vol. 7: From 1905-1940, pp. 460-493, Cambridge University Press, Cambridge.

Jules-Rosette, B., 1980, 'Creative spirituality from Africa to America: Cross-cultural influences in contemporary religious forms', Western Journal of Black Studies 4(4), 273-285.

Kahl, W., 1998, 'Überlegungen zu einer interkulturellen Verständigung über Neutestamentliche Wunder [Reflections on a cross-cultural understanding on New Testament miracles]', Zeitschrift für Missionswissenschaft und Religionswissenschaft 82(2), 98-106.

Kalu, O., 2008, African Pentecostalism: An introduction, Oxford University Press, Oxford.

Kaplan, B. \& Johnson, D., 1964, 'The social meaning of Navajo psychopathology and psychotherapy', in A. Kiev (ed.), Magic, faith, and healing: Studies in primitive psychiatry today, pp. 203-229, Free Press, Macmillan, New York.

Keener, C.S., 2005, "'Brood of vipers" (Mt. 3.7; 12.34; 23.33)', Journal for the Study of the New Testament 28(1), 3-11.

Keener, C.S., 2009a, 'Fever and dysentery in Acts 28:8 and ancient medicine', Bulletin for Biblical Research 19(3), 393-402.

Keener, C.S., 2009b, The Gospel of Matthew: A socio-rhetorical commentary, Eerdmans, Grand Rapids.

Keener, C.S., 2009c, The historical Jesus of the Gospels, Eerdmans, Grand Rapids.

Keener, C.S., 2009d, 'Human stones in a Greek setting - Luke 3.8//Matthew 3.9; Luke 19.40', Journal of Greco-Roman Christianity and Judaism 6, 28-36.

Keener, C.S., (in press), 'Spirit possession as a cross-cultural experience', Bulletin for Biblical Research 20.

Keener, C.S., (in press), 'Miracles: The plausibility of healing accounts in the Gospels and Acts', Hendrickson, Peabody.

Kidd, T.S., 2006, 'The healing of Mercy Wheeler: Illness and miracles among early American evangelicals', William and Mary Quarterly 63(1), 149-170.

Kim, S.-G., 2006, 'Pentecostalism, shamanism and capitalism within contemporary Korean society', in S.J. Stålsett (ed.), Spirits of globalization: The growth of Pentecostalism and experiential spiritualities in a global age, pp. 23-38, SCM, London.

Klutz, T., 2004, The exorcism stories in Luke-Acts: A sociostylistic reading, Society for New Testament Studies Monograph Series 129, Cambridge University Press, Cambridge.

Koschorke, K., Ludwig, F. \& Delgado, M. (eds.), with R. Spliesgart, 2007, History of Christianity in Asia, Africa, and Latin America, 1450-1990: A documentary sourcebook, Eerdmans, Grand Rapids.

Krippner, S. \& Achterberg, J., 2000, 'Anomalous healing experiences', in E. Cardeña, S.J. Lynn \& S. Krippner (eds.), Varieties of anomalous experience: Examining the scientific evidence, pp. 353-396, American Psychological Association, Washington DC.

Laing, M., 2006, 'The changing face of mission: Implications for the southern shift in Christianity', Missiology 34(2), 165-177.

Lewis, D.C., 1989, Healing: Fiction, fantasy, or fact?, Hodder \& Stoughton, London.

Lewis, I.M., 1969, 'Spirit possession in northern Somaliland', in J. Beattie \& J. Middleton (eds.), Spirit mediumship and society in Africa, pp. 188-219, Africana Publishing Corporation, New York.

Lewis, I.M., 1971, Ecstatic religion: An anthropological study of spirit possession and shamanism, Penguin, Baltimore.

Luling, V., 1991, 'Some possession cults in southern Somalia', in I.M. Lewis, A. Al-Safi \& S. Hurreiz (eds.), Women's medicine: The Zar-Bori cult in Africa and beyond, pp. 167-177, Edinburgh University Press, Edinburgh.

Ma, J., 1999, 'Pentecostal challenges in East and South-East Asia', in M.W. Dempster, B.D. Klaus \& D. Petersen (eds.), The globalization of Pentecostalism: A religion made to travel, pp. 183-202, Paternoster, Carlisle.

Ma, W., 2005, 'Asian (classical) Pentecostal theology in context', in A. Anderson \& E. Tang (eds.), Asian and Pentecostal: The charismatic face of Christianity in Asia, pp. 59-91, Regnum, Oxford. 
MacMullen, R., 1984, Christianizing the Roman Empire, Yale University Press, New Haven.

Manus, C.U., 1989, 'Miracle-workers/healers as divine men: Their role in the Nigerian church and society', Asia Journal of Theology 3(2), 658-669.

Martell-Otero, L.I., 2004, 'Liberating news: An emerging U.S. Hispanic/Latina soteriology of the crossroads', PhD dissertation, Department of Theology, Fordham University.

Martin, D.B., 1995, The Corinthian body, Yale University Press, New Haven.

Martin, M.-L., 1975, Kimbangu: An African prophet and his church, Basil Blackwell, Oxford.

Maxwell, D., 2006, African gifts of the Spirit: Pentecostalism and the rise of a Zimbabwean transnational religious movement, James Currey, Oxford.

Mbiti, J.S., 1970, African religions and philosophies, Doubleday \& Company, Garden City.

McClymond, M.J., 2004, Familiar stranger: An introduction to Jesus of Nazareth, Eerdmans, Grand Rapids.

Mchami, R.E.K., 2001, 'Demon possession and exorcism in Mark 1:21-28', Africa Theological Journal 24(1), 17-37.

Mensah, F.A., 2008, 'The spiritual basis of health and illness in Africa', in T. Falola \& M.M. Heaton (eds.), Health knowledge and belief systems in Africa, pp. 171-180, Carolina Academic Press, Durham.

Morsy, S.A., 1991, 'Spirit possession in Egyptian ethnomedicine: Origins, comparison and historical specificity', in I.M. Lewis, A. Al-Safi \& S. Hurreiz (eds.), Women's medicine: The Zar-Bori cult in Africa and beyond, pp. 189-208, Edinburgh University, Edinburgh.

Moussounga Keener, M., 2005, 'Daniel Ndoundou', Dictionary of African Christian biography, viewed n.d., from http://www. dacb.org/stories/congo/ndoundou_daniel.html

Mullin, R.B., 2008, A short world history of Christianity, Westminster John Knox, Louisville.

Ndofunsu, D., 1978, 'The role of prayer in the Kimbanguist Church', in E. Fasholé-Luke, R. Gray, A. Hastings \& G. Tasie (eds.), Christianity in independent Africa, pp. 577-596, Indiana University Press, Bloomington.

Neyrey, J.H., 1999, 'Miracles, in other words: Social science perspectives on healings', in J.C. Cavadini (ed.), Miracles in Jewish and Christian antiquity: Imagining truth, Notre Dame Studies in Theology 3, pp. 19-56, University of Notre Dame, Notre Dame.

Noll, M.A., 2009, The new shape of world Christianity: How American experience reflects global faith, IVP Academic, Downers Grove.

Oesterreich, T.K., 1966, Possession: Demoniacal and other among primitive races, in antiquity, the Middle Ages, and modern times, University Books, New Hyde Park.

Orr, J.E., 1975, Evangelical awakenings in Africa, Bethany, Minneapolis.

Peters, L., 1981, Ecstasy and healing in Nepal: An ethnopsychiatric study of Tamang shamanism, Undena, Malibu.

Petersen, D., 1996, Not by might nor by power: A Pentecostal theology of social concern in Latin America, Regnum, Oxford.

Petersen, D., 2006, 'The Azusa Street Mission and Latin American Pentecostalism', International Bulletin of Missionary Research 30(2), 66-67.

Pew Forum Survey, 2006, 'Spirit and power: A 10-country survey of Pentecostals', viewed 04 January 2009, from http://pewforum.org/surveys/pentecostal

Pilch, J.J., 1995, 'Insights and models from medical anthropology for understanding the healing activity of the historical Jesus', HTS Teologiese Studies/Theological Studies 51(2), 314-337.

Pilch, J.J., 2000, Healing in the New Testament: Insights from medical and Mediterranean anthropology, Fortress, Minneapolis.

Pilch, J.J., 2004, Visions and healing in the Acts of the Apostles: How the early believers experienced God, Liturgical Press, Collegeville.

Pilch, J.J., 2008, 'The usefulness of the meaning response concept for interpreting translations of healing accounts in Matthew's Gospel', in D. Neufeld (ed.), The social sciences of biblical translation, SBLSymS 41, pp. 97-108, Society of Biblical Literature, Atlanta.
Pocock, M., Van Rheenen, G. \& McConnell, D., 2005, The changing face of world missions: Engaging contemporary issues and trends, Baker Academic, Grand Rapids.

Porterfield, A., 2005, Healing in the history of Christianity, Oxford University Press, Oxford.

Porterfield, A., 2006, 'Shamanism as a point of departure: Two courses on Christianity and healing', in L.L. Barnes \& I. Talamantez (eds.), Teaching religion and healing, pp. 159-169, Oxford University Press, Oxford.

Price, R.M., 2003, The incredible shrinking Son of Man: How reliable is the Gospel tradition?, Prometheus, Amherst.

Prince, R., 1968, 'Can the EGG be used in the study of possession states?', in R. Prince (ed.), Trance and possession states, pp. 121-137, R.M. Bucke Memorial Society, Montreal.

Remus, H., 1997, Jesus as healer, Cambridge University Press, Cambridge.

Richards, W., 2005, 'An examination of common factors in the growth of global Pentecostalism: Observed in South Korea, Nigeria and Argentina', Journal of Asian Mission 7(1), 85-106.

Roschke, R.W., 2006, 'Healing in Luke, Madagascar, and elsewhere', Currents in Theology and Mission 33(6), 459-471.

Sanneh, L., 2003, Whose religion is Christianity? The Gospel beyond the West, Eerdmans, Grand Rapids.

Sanneh, L., 2008, Disciples of all nations: Pillars of world Christianity, Oxford University Press, Oxford.

Scherberger, L., 2005, 'The Janus-faced shaman: The role of laughter in sickness and healing among the Makushi', Anthropology and Humanism 30(1), 55-69.

Shank, D.A., 1994, Prophet Harris: The 'Black Elijah' of West Africa, Brill, Leiden.

Shorter, A., 1985, Jesus and the witchdoctor: An approach to healing and wholeness, Geoffrey Chapman, London.

Singleton, M., 1978, 'Spirits and "spiritual direction": The pastoral counselling of the possessed', in E. Fasholé-Luke, R. Gray, A. Hastings \& G. Tasie (eds.), Christianity in independent Africa, pp. 471-478, Indiana University, Bloomington.

Southall, A., 1969, 'Spirit possession and mediumship among the Alur', in J. Beattie \& J. Middleton (eds.), Spirit mediumship and society in Africa, pp. 232-272, Africana Publishing Corporation, New York.

Stoller, P. \& Olkes, C., 1987, In sorcery's shadow: A memoir of apprenticeship among the Songhay of Niger, University of Chicago, Chicago.

Straight, B., 2007, Miracles and extraordinary experience in northern Kenya, University of Pennsylvania, Philadelphia.

Taliaferro, C. \& Hendrickson, A., 2002, 'Hume's racism and his case against the miraculous', Philosophia Christi 4(2), 427-441.

Ten, C.L., 2002, 'Hume's racism and miracles', Journal of Value Inquiry 36, 101-107.

Theissen, G. \& Merz, A., 1998, The historical Jesus: A comprehensive guide, Fortress, Minneapolis.

Tippett, A.R., 1976, 'Spirit possession as it relates to culture and religion: A survey of anthropological literature', in J.W. Montgomery (ed.), Demon possession: A medical, historical, anthropological and theological symposium, papers presented at the University of Notre Dame, Notre Dame, January 08-11, 1975, pp. 143-174, Bethany House, Minneapolis.

Turner, E., 2006, Among the healers: Stories of spiritual and ritual healing around the world, Praeger, Westport.

Turner, E., Blodgett, W., Kahoma, S. \& Benwa, F., 1992, Experiencing ritual: A new interpretation of African healing, University of Pennsylvania Press, Philadelphia.

Van Aarde, A., 2008, " Anthropological rabbits" and "positivistic ducks": An experiential reflection on Peter Craffert's "shamanistic Jesus"', HTS Teologiese Studies/Theological Studies 64(2), 767-798.

Van der Watt, J.G., 2008, 'A hermeneutics of relevance: Reading the Bible in dialogue in African contexts', in J. Verheyden, G. van Belle \& J.G. van der Watt (eds.), Miracles and imagery in Luke and John: Festschrift Ulrich Busse, Bibliotheca Ephemeridum Theologicarum Lovaniensium 218, pp. 237-255, Uitgeverij Peeters, Leuven. 
Verger, P., 1969, 'Trance and convention in Nago-Yoruba spirit mediumship', in J. Beattie \& J. Middleton (eds.), Spirit mediumship and society in Africa, pp. 50-66, Africana Publishing Corporation, New York.

Walker, S.S., 1983, The religious revolution in the Ivory Coast: The Prophet Harris and his church, University of North Carolina Press, Chapel Hill.

Walls, A.F., 1996, The missionary movement in Christian history: Studies in the transmission of faith, T\&T Clark, Edinburgh.

Weissenrieder, A., 2003, Images of illness in the Gospel of Luke: Insights of ancient medical texts, Wissenschaftliche Untersuchungen sum Neuen Testament 2, Reihe 164, Mohr Siebeck, Tübingen.

Winkelman, M. \& Carr, C., 2006, 'Teaching about shamanism and religious healing: A cross-cultural, biosocial-spiritual approach', in L.L. Barnes \& I. Talamantez (eds.), Teaching religion and healing, pp. 171-190, Oxford University Press, Oxford.
Wright, J.S., 1955, Man in the process of time: A Christian assessment of the powers and functions of human personality, Eerdmans, Grand Rapids.

Yong, A., 2005, The Spirit poured out on all flesh: Pentecostalism and the possibility of global theology, Baker, Grand Rapids.

Yong, J.J., 2005, 'Filipino independent Pentecostalism and biblical transformation', in A. Anderson \& E. Tang (eds.), Asian and Pentecostal: The charismatic face of Christianity in Asia, pp. 385-407, Regnum, Oxford.

Yung, H., 2005, 'Pentecostalism and the Asian Church', in A. Anderson \& E. Tang (eds.), Asian and Pentecostal: The charismatic face of Christianity in Asia, pp. 37-57, Regnum, Oxford.

Yung, H., 2007, 'The integrity of mission in the light of the Gospel: Bearing the witness of the Spirit, Mission Studies 24, 169-188. 